\title{
Olga Lucía Jordán, el ojo sensible
}

Juan Gustavo Cobo Borda

Escritor y poeta

Doctor en Humanidades y Letras

coborda@gmail.com

\section{Resumen}

Las fachadas coloniales de casas y

fincas del eje cafetero colombiano son

protagonistas de las fotografías que

aparecen en esta edición de Poliantea,

parte de la obra de la artista colombiana

Olga Lucía Jordán. A estas atmósferas de color, luz y sombras se acerca Juan Gustavo Cobo Borda para navegar por las historias que atraviesan las

balaustradas del paisaje cultural cafetero de Colombia.

Palabras clave: fachadas, eje cafetero,

fotografía, 
- Olga Lucía Jordán, el ojo sensible - Juan Gustavo Cobo Borda 
Unos treinta libros ilustrados con fotografías suyas integran el aporte visible de Olga Lucía Jordán a la configuración de una estética de la colonización antioqueña, por los caminos del Quindío y Risaralda. Graduada como artista en la Universidad Nacional, se encaminó hacia la fotografía, luego de estancias en Europa, donde ha sobresalido de modo indiscutible en dos campos. Por una parte, en sus retratos de artistas en el interior de sus estudios, que abarcan 239 figuras reunidas en el número 38-39 de abril de 2011 de la revista Mundo, algunas de las cuales habían aparecido años antes en el libro 20 artistas en la cocina, de Consuelo Mendoza Ediciones (noviembre de 2006, Bogotá). Por otra, al fotografiar los 47 municipios en los departamentos de Caldas, Quindío, Risaralda y Valle del Cauca, donde unas 24 mil fincas cafeteras lograron que en junio de 2011 el
Comité de Patrimonio Mundial de la Unesco declarara el Paisaje Cultural Cafetero de Colombia como patrimonio cultural de la humanidad. De allí esas colinas sombreadas de verdes de todos los colores, de allí esas palmas de cera, esas flores y esos pájaros exuberantes de vivacidad y color.

Pero no solo exteriores $y$ atmósferas han sido captadas con amorosa sensibilidad. El interior de esas fincas, con patios y corredores circundados con materas que cuelgan airosas, donde recorremos balcones y ventanas, celosías con su bien trenzado encaje en madera que siluetea sobre la blanca cal de los muros su alfabeto de volutas, orlas y abiertos ojos o barrotes. La guadua como material maleable. La honda y luminosa perspectiva que desde el portón o la sala se prolonga en patios y solares, donde los bancos de madera para la contemplación o el 
diálogo nos hablan de una comunidad en que anciano y niñas, con gato incluido, descorren cortinas y se asoman, recatados o traviesos a ese mundo donde el guayacán desgrana su nieve amarilla. Y los jinetes, con negro bigote, hacen saltar chispas del empedrado o siguen tranquilos su recua de mulas.

Allí, en esa geometría del rectángulo y de la balaustrada, honra a los diestros artesanos que moldean los vanos y las sombras como la música del amanecer a la noche. Todo un mundo tradicional y religioso, donde los inmigrantes van por la cordillera talando selva, sembrando el pan coger, revistiendo de colores intensos esas casas tan firmes como frescas, máximo dos pisos, abiertas siempre al horizonte, a las brisas perfumadas, a la integración con quien, viniendo de lejos, pronto trabajará en la cosecha y no muy tarde será vecino y contertulio en la plaza del pueblo, en la tienda donde todo se consigue, incluso la conversada cerveza o el ritual aguardiente. Que siempre tendrán detrás suyo, como marco, talladores y ebanistas de raigambre popular que forjan así el espacio hospitalario de los sueños, en los juegos reposados de la luz advertidos y recreados con deleite visual en estas fotos. Atentas a esos calados o volutas asimétricas de tanto encanto. Un aire familiar que alcanza a recorrer muchos cuadros de Fernando Botero, fijando los rectángulos rojos de esos patios con banano incluido o el relato de Álvaro Mutis, "La mansión de Araucaima", hacienda cafetera con sus habitantes arquetípicos sacudidos por el vendaval del deseo. Porque estas casas, esas puertas ventanas, protegen la intimidad, pero se abren también al vaivén de transeúntes, a las cabalgatas de feria, a las chivas multicolores, a lo que Olga Lucía Jordán ha tornado perdurable en sus fotos ya clásicas de su terruño natal. 